\title{
Correction
}

\section{Correction: Krokidis, M.G., et al. Oxygen-Dependent Accumulation of Purine DNA Lesions in Cockayne Syndrome Cells. Cells 2020, 9, 1671}

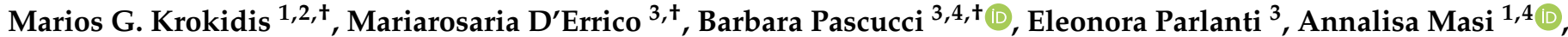 \\ Carla Ferreri ${ }^{1}$ (D) and Chryssostomos Chatgilialoglu $1,5, * \mathbb{D}$
}

check for updates

Citation: Krokidis, M.G.; D’Errico, M.; Pascucci, B.; Parlanti, E.; Masi, A.; Ferreri, C.; Chatgilialoglu, C.

Correction: Krokidis, M.G., et al. Oxygen-Dependent Accumulation of Purine DNA Lesions in Cockayne Syndrome Cells. Cells 2020, 9, 1671 Cells 2021, 10, 41. https://doi.org/ $10.3390 /$ cells 10010041

Received: 27 October 2020

Accepted: 23 November 2020

Published: 30 December 2020

Publisher's Note: MDPI stays neutral with regard to jurisdictional clai$\mathrm{ms}$ in published maps and institutional affiliations.

Copyright: () 2020 by the authors. Licensee MDPI, Basel, Switzerland. This article is an open access article distributed under the terms and conditions of the Creative Commons Attribution (CC BY) license (https:// creativecommons.org/licenses/by/ $4.0 /)$.
1 Istituto per la Sintesi Organica e la Fotoreattività, Consiglio Nazionale delle Ricerche, Via P. Gobetti 101, 40129 Bologna, Italy; m.krokidis@inn.demokritos.gr (M.G.K.); annalisa.masi@ic.cnr.it (A.M.); carla.ferreri@isof.cnr.it (C.F.)

2 Institute of Nanoscience and Nanotechnology, N.C.S.R. "Demokritos", Agia Paraskevi Attikis, 15310 Athens, Greece

3 Department of Environment and Health, Istituto Superiore di Sanità, Viale Regina Elena 299, 00161 Rome, Italy; mariarosaria.derrico@iss.it (M.D.); barbara.pascucci@ic.cnr.it (B.P.); eleonora.parlanti@iss.it (E.P.)

4 Institute of Crystallography, Consiglio Nazionale delle Ricerche, Monterotondo Stazione, 00015 Rome, Italy

5 Center for Advanced Technologies, Adam Mickiewicz University, 61-614 Poznań, Poland

* Correspondence: chrys@isof.cnr.it; Tel.: +39-051-639-8309

+ These authors contributed equally to this paper.

The originally published article [1] contains an error in the depiction of the structures of adenine derivatives in Figure A1 (Appendix A).

The correct structures are shown below.

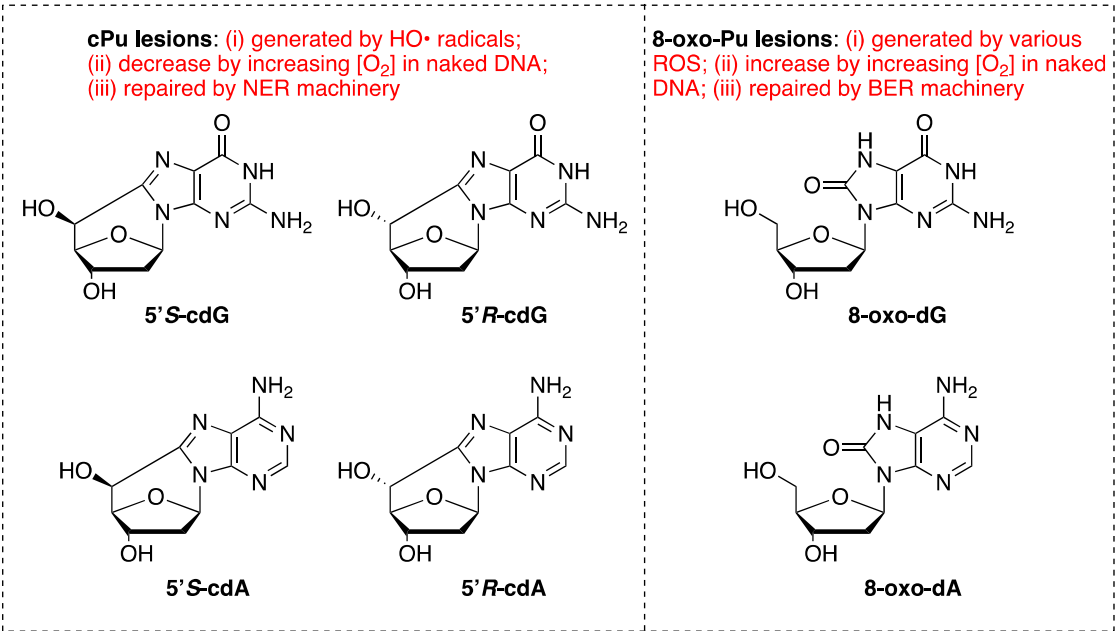

The authors would like to apologize for any inconvenience this has caused the readers. The change does not affect the scientific results.

\section{Reference}

1. Krokidis, M.G.; D’Errico, M.; Pascucci, B.; Parlanti, E.; Masi, A.; Ferreri, C.; Chatgilialoglu, C. Oxygen-Dependent Accumulation of Purine DNA Lesions in Cockayne Syndrome Cells. Cells 2020, 9, 1671. [CrossRef] [PubMed] 